\title{
INCREASING EFFICIENCY OF GRINDING PROCESS IN SINGLE-ROLLER GRAIN MILL
}

\author{
Yaroslav Myhailovych, Svitlana Potapova, Oksana Achkevych, Vasyl Achkevych \\ National University of Life and Environmental Sciences of Ukraine, Ukraine \\ yaroslav_m@ukr.net, svitlapotapova@gmail.com, achkevych@gmail.com, achkevychv@gmail.com
}

\begin{abstract}
The article is devoted to increasing the efficiency of the process of grinding grain feed in the conditions on farms by optimizing the design and technological parameters of a single-roller grain crusher. The main researches of technologies and technical means for grain grinding are analyzed. It is established that the actual direction of increasing the efficiency of grain grinding equipment for farms is the improvement of roller grinders, in particular single-roller (roller) crushers. According to the results of the experiments, the dependences of energy and quality indicators of the grain grinding process on the controlled parameters: roller rotation speed, angle of inclination of the guide, angle of the girth crushing plate, size of the working gap are obtained. Based on the research, the rational parameters are recommended, which will reduce the energy consumption and improve the quality of grinding products.
\end{abstract}

Keywords: single-roller grain mill, qualitative indicators.

\section{Introduction}

Various grinders [1-4] can be used in agricultural production and feed processing, but hammer crushers are the most common. Compared to most other feed processing machines, they are characterized by simplicity of the design and maintenance, wide versatility. But these machines have significant drawbacks. These include, first of all, the high energy consumption of the process and the large unevenness of the particle size distribution of the grinding products.

Therefore, it is advisable to find other, more advanced means of grinding grain feed. The analysis of literature sources shows that the development is carried out in the direction of reducing energy consumption and grinding quality. The author in [5] describes issues related to evaluation of the efficiency of grinding raw materials in the crusher under the action of an electromagnetic field. The expected effect of using a system based on an electromagnetic crusher is to provide lower energy consumption for grinding of raw materials. In study [6] the technical conditions of using a roller mill with a new design of the working unit of rollers are presented and analyzed. The relationship was established: motion, particle size of ground rice grains, displacement and grinding on a roller-plate crusher. It is shown that the relationship between the motion, the state of the particles and the values of the grinding indices depend, among other things, on the conditions of friction, collision, cutting, new design features of the mill. The author in study [7] presents the results when using a centrifugal impact crusher of a new design with a hole in the loading neck to supply additional air at a speed of up to 4.8 $\mathrm{m} \cdot \mathrm{s}^{-1}$. Regression equations are derived to determine the structural and regime parameters of the shredder, which provide maximum productivity and minimum unit energy costs. It was found that the greatest influence on the performance of the crusher is exerted by the diameter of the sieve holes and the area of the unloading window of the hopper. In study [8] the analysis of the hammer crusher is given and the diameter of the screen hole and the thickness of the hammer were established and had a significant effect on energy consumption. It was found that such quality indicators as the hole diameter and the speed of the hammer had a significant impact on the quality of grinding. The thickness of the hammer, on the contrary, had little effect on the quality of grinding. The authors in [9] propose a method for assessing the effectiveness of the process of grinding grain materials based on the actual implementation of technological processes. The ability to assess this indicator is achieved by differentiating the mass of the finished crushed product into three fractions: the required size, undercut and re-crushed, and the last two of them are of poor quality, which requires further influence on them. The proposed theoretical model characterizes this process from the qualitative aspect of its implementation. In study [10] the author gives a comparative assessment of the effectiveness of different types of grinders of grain materials and the use of different approaches to determine the quality of grinding.

The information sources analysis shows that the roller machines can be capable of ensuring high quality (uniformity) of feed grinding. In particular, these are roller mills in single-roller version. Their 
design simplicity, low cost and low energy consumption will be especially attractive for small farms and private farms.

The optimization of the design and technological parameters of a single-roller mill can give a new solution to the problem of improving the quality and reducing the energy consumption of the process of grinding grain feed in the conditions of farms.

\section{Materials and methods}

Theoretical research was conducted using the basic principles of higher mathematics and theoretical mechanics. Experimental studies were performed in the laboratory using methods of planning multifactorial experiments and statistical processing of experimental data using appropriate software products (Microsoft Excel, Statistica).

Grain feeds (barley, corn), which are most often used in the diets of farm animals, are taken as the basic raw material for the research.

The features of the presented scheme, Fig. 1, are: presence of directing the processed raw materials directly to a working clearance; the ability to adjust the angle of inclination and the size of the input gap depending on the type of the raw material.

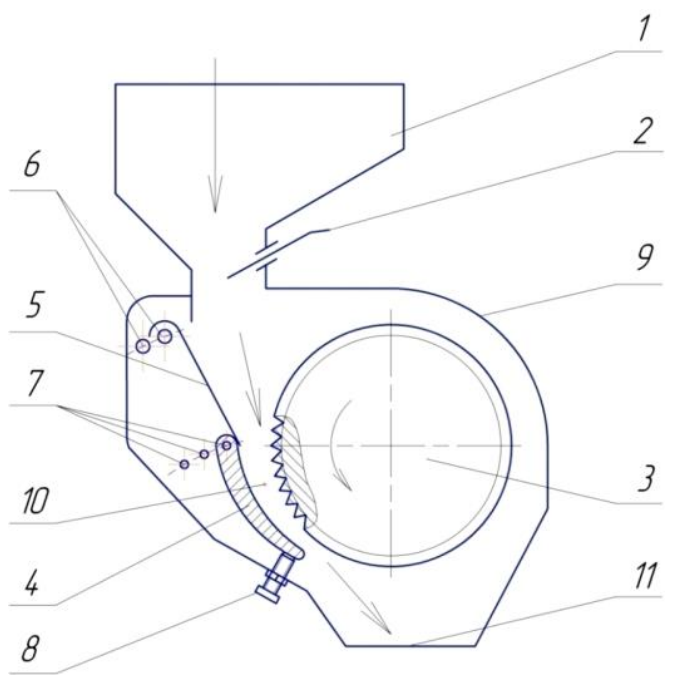

Fig. 1. Structural and functional scheme of the crusher: 1 - grain hopper; 2 -adjusting valve; 3 roller; 4 -crushing plate; 5 - guide; 6,7 -fasteners in accordance with guide and crushing plate; 8 adjusting screw; 9 - housing; 10 - working area (gap); 11 - outlet

To conduct experimental studies according to the developed structural and functional scheme, Fig. 2, an installation was made for grinding grain feed. The experimental setup includes, Fig. 2: a storage hopper with an adjusting valve, a working chamber with a guide, a crushing plate and a roller inside and an outlet. The surface of the roller is corrugated, the crushing plate is smooth. The diameter of the roller is $230 \mathrm{~mm}$. To change the way of grain processing, a variable crushing plate were used, Fig. 3, with a different girth angle $\gamma$. The ranges of variable factors are summarized in Table 1.

Table 1

Ranges of variable factors of the single-roller mill

\begin{tabular}{|l|c|c|c|c|c|}
\hline \multirow{2}{*}{ Variable factors } & \multicolumn{3}{|c|}{ Levels of variation } & \multirow{2}{*}{$\begin{array}{c}\text { Intervals of } \\
\text { variation }\end{array}$} \\
\cline { 3 - 5 } & $n$ & -1 & 0 & 1 & \\
\hline Roller speed, rpm $^{*}$ & $n$ & 165 & 270 & 105 \\
\hline Angle of inclination of the guide, $^{\circ}$ & $\beta$ & 40 & 55 & 70 & 15 \\
\hline Angle of the girth crushing plate, $^{\mathbf{o}}$ & $\gamma$ & 10 & 25 & 40 & 15 \\
\hline Gap, mm $^{*} \mathrm{~mm}$ & $\delta$ & 0.5 & 1.5 & 2.5 & 1 \\
\hline
\end{tabular}

The experimental setup allowed: 
- adjust the speed of the roller with a variator;

- change the angle of the guide;

- install one of the three crushing plates with the appropriate angle of girth;

- change the size of the working gap between the roller and the crushing plate.

During the laboratory research, the following energy indicators were determined: power consumed by the electric drive of the experimental installation at idle and under load; specific energy consumption. The readings were taken using current measuring tongs Mastech MS 3302.

An external ADC/DAC module E14-140M connected to a personal computer was used to convert and process the obtained data. The processing time each portion of feed material was recorded with a stopwatch. The rotation speed of the roller was measured with a tachometer.

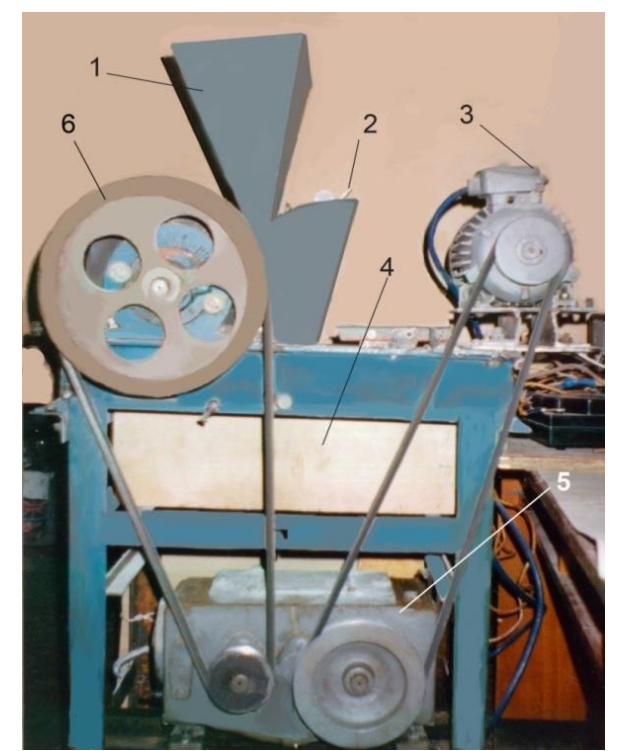

Fig. 2. General view of the experimental

installation: 1 - grain hopper; 2 - guide; 3 - electric motor; 4 - box for the finished product; 5 - variator; 6 - drive pulley

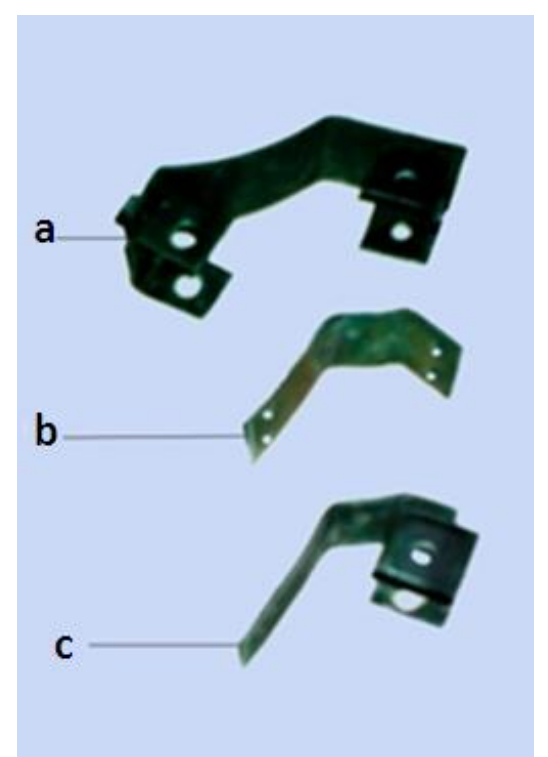

Fig. 3. Types of studied plates:

a - crushing plate $\left(\gamma=45^{\circ}\right)$;

$\mathrm{b}$ - crushing plate $\left(\gamma=25^{\circ}\right)$;

$\mathrm{c}-$ crushing plate $\left(\gamma=10^{\circ}\right)$

The quality of feed grinding was evaluated by sieving their portion (weighing $100 \mathrm{~g}$ ) on a sieve classifier. The sieve classifier consisted of four sieves with holes, respectively $0.2 ; 1 ; 2 ; 3 \mathrm{~mm}$. Samples were weighed on laboratory scales VLR-200 g, the error of which is $0.5 \mathrm{mg}$.

\section{Results and discussion}

The technological process of grain processing by such a crusher consists of three, Fig. 4, successive stages. The first stage (I) - tightening and elastic deformation occurs from the moment of application of the forces caused by the action of the working bodies of the crusher until the appearance of the first cracks, which corresponds to the elastic limit of the grain. The second stage (II) - plastic deformation and displacement of individual parts of the grain. At this time, the grain begins to split, sometimes flattened (compacted). After that there is a transition to the decisive, third stage (III) - grinding of grain into particles of the set size.

Experimental studies were performed to establish rational design and kinematic parameters of the roller crusher. The criteria for optimizing the technological process were:

- grinding module $M$ (average size of crushed particles), mm;

- coefficient of variation the fractional composition $v, \%$;

- productivity of installation $Q, \mathrm{~kg} \cdot \mathrm{h}^{-1}$;

- $\quad$ specific energy consumption of the grinding process $q, \mathrm{kWh} \cdot \mathrm{t}^{-1}$. 


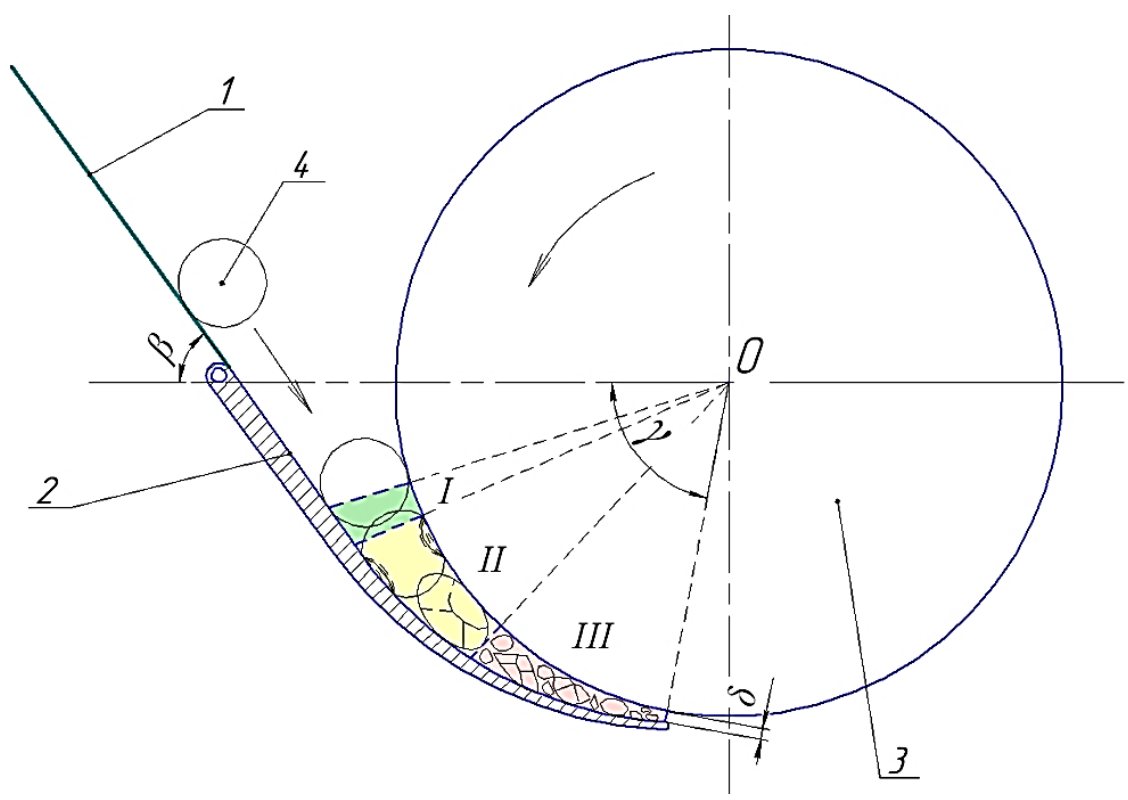

Fig. 4. Model of the process of grinding grain with a roller: 1 - guide; 2 - crushing plate; 3 - roller; 4 - grain

After processing the experimental data on a PC, using the application program STATISTICA 6.1, the regression equation was obtained. Mathematical models after determining the significant regression coefficients and decoding for ease of use of equations in the calculations took the following form.

- For barley:

$$
\begin{aligned}
& M_{b}= 0.5813-0.0021 n-0.0398 \gamma+0.1271 \delta+0.0002 \beta \gamma-0.0005 \beta^{2}+0.0004 \gamma^{2}+0.1765 \delta^{2} ; \\
& v_{b}= 14.2452-0.0427 n-0.2169 \beta+6.3465 \delta+0.0121 \beta \delta-0.0001 n^{2}+0.0022 \beta^{2}-3.3231 \delta^{2} ; \\
& q_{b}=-4.0741+0.0222 n+0.1469 \beta+1.0058 \delta-0.0005 n \beta-0.0029 n \delta-0.0611 \gamma \delta-0.0044 \gamma^{2} ; \\
& \quad Q_{b}=69.3408-0.0693 n-1.386 \gamma-0.3817 \delta+0.0024 n \beta+0.016 n \delta+0.0087 \beta \gamma \\
& \quad+0.1017 \gamma \delta+0.0113 \gamma^{2} .
\end{aligned}
$$

- For corn:

$$
\begin{aligned}
& M_{c}=1.3649-0.0041 n-0.0494 \gamma+0.1591 \delta+0.00001 n \gamma+0.0004 \beta \gamma+0.0038 \beta \delta+ \\
& +0.0004 \gamma^{2}+0.1031 \delta^{2} ; \\
v_{c} & =23.067-0.0193 n+0.019 \gamma+1.781 \delta+0.0003 n \gamma+0.0015 \beta \gamma+0.0344 \gamma \delta+0.924 \gamma^{2} ; \\
& q_{c}=2.7683-0.0715 n+0.1065 \gamma-0.5046 \delta+0.0001 n \gamma-0.0014 \beta \gamma+0.0098 \beta \delta- \\
& -0.0265 \gamma \delta+0.0013 \beta^{2} ; \\
Q_{c}= & 56.5919+0.002 n-1.4829 \gamma+1.1066 \delta+0.0016 n \beta+0.0079 \beta \gamma+0.116 \gamma \delta+0.0134 \gamma^{2} .
\end{aligned}
$$

The analysis of the obtained dependences shows that in general the nature of the influence of variable factors on the magnitude of the modulus of grinding $M$ in the processing of different crops is the same, but for barley were obtained larger values of $M$. This is due to the higher strength of barley grains. The largest indicator $M$ depends on the size of the working gap $\delta$, which limits the final particle size. The roller rotation speed $n$ has a slightly smaller effect on the value of $M$. The angle of inclination $\beta$ of the guide has almost no effect on the value of $M$.

When studying the influence of variable factors on the coefficient of variation of grinding products for barley, the value $v$ was in the range of $9-20 \%$, for corn $16-23 \%$. The difference is due to the difference in physical and mechanical properties of these crops. Simultaneous increase of the angle $\gamma$ of the girth 
of the roller deck and the roller rotation speed $n$ leads to an intensive increase of the coefficient of variation $v$. The most significant effect on the value of the coefficient of variation has a change in the working gap $\delta$.

Reducing the value of the angle $\gamma$ of the girth crushing plate leads to an increase in the productivity, but at large values of the working gap $\delta$ the effect of $\gamma$ is leveled. With increasing the size of the working gap $\delta$, as well as the roller rotation speed $n$, the productivity of the crusher increases, because it accelerates the speed of the passage of the processed material working area.

As the working gap $\delta$ increases, the specific energy intensity $q$ decreases, and the smaller the values of the angle inclination $\beta$, the more intense the effect $\delta$. The energy consumption of the process grinding barley, the grains of which are stronger, is higher than for corn. With increasing the roller rotation speed $n$ and simultaneous increase in the angle of inclination of the guide $\beta$, the specific energy consumption of the process increases sharply.

Examples of dependences of optimization criteria on the main controlled factors are given in Fig. 5-6.
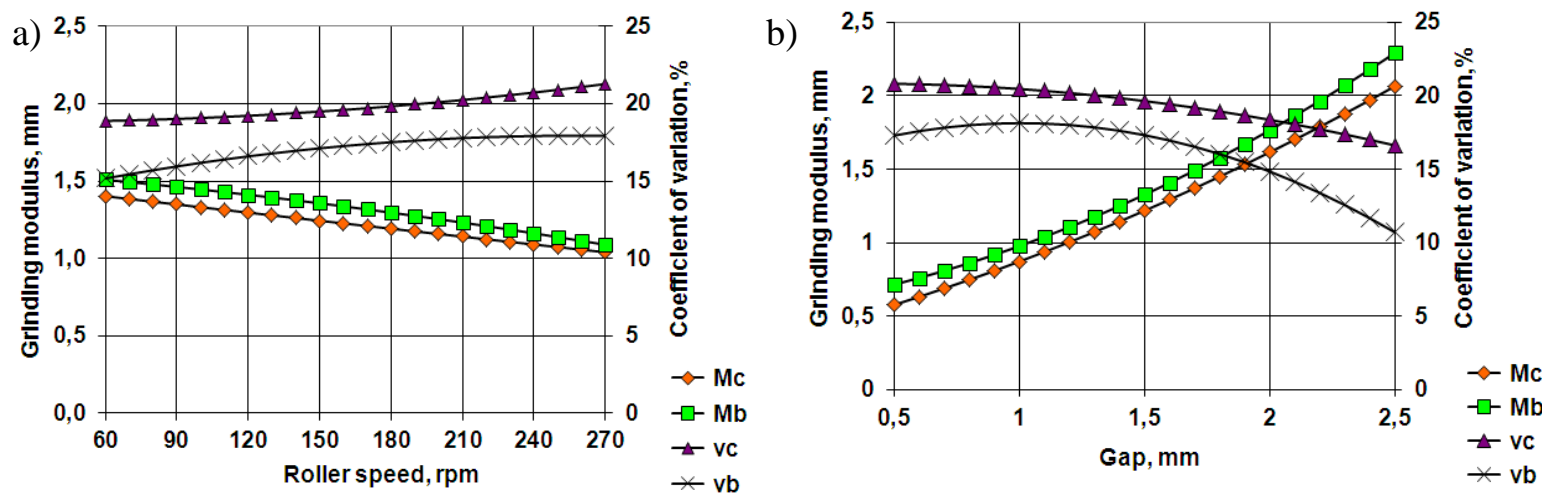

Fig. 5. Dependences of the grinding modulus of $\operatorname{corn} M_{c}$ and barley $M_{b}$ and the coefficient of variation of $v_{c}$ and $v_{b}$, respectively, on the roller speed $n$ (a) and on the value of the working gap $\delta$ between the roller and the crushing plate (b)

a)

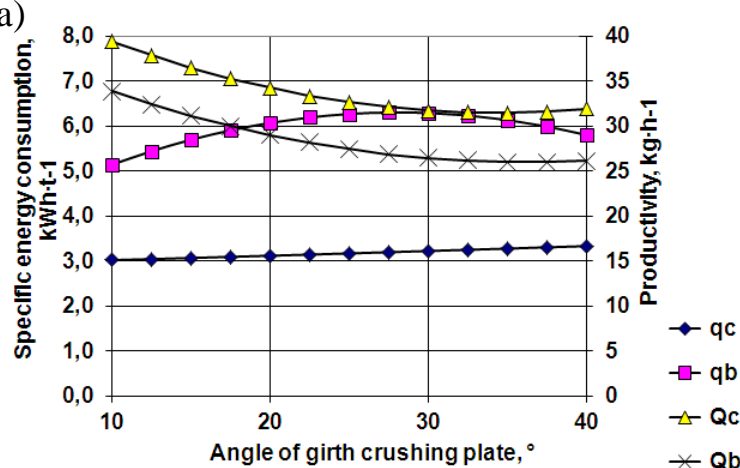

b)

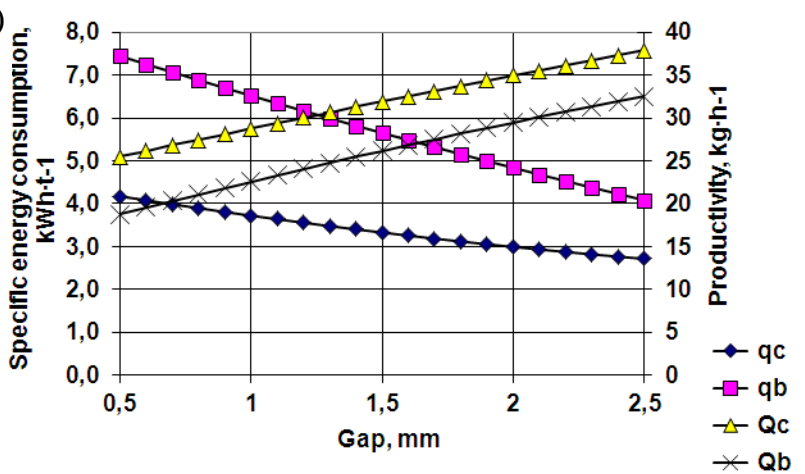

Fig. 6. Dependences of specific energy consumption $q_{c}$ and $q_{b}$ and productivity $Q_{c}$ and $Q_{b}$ when grinding corn and barley, respectively, on the angle $\gamma$ of the girth crushing plate (a) and on the working gap $\delta$ between the roller and the crushing plate (b)

The analysis of the obtained dependences makes it possible to make recommendations on the rational parameters of the crusher. For example, in the case of grinding barley grain to the average size of the product $M=1.29 \mathrm{~mm}$ (gap $1.5 \mathrm{~mm}$ ) the values are as follows: the roller speed $n=160 \mathrm{rpm}$, the angle of the guide $\beta=70^{\circ}$, the angle of the girth crushing plate $\gamma=10^{\circ}$. At these values of these factors, the specific energy consumption is $5.16 \mathrm{kWh} \cdot \mathrm{t}^{-1}$ with a coefficient of variation of the fractional composition $v=17.94 \%$.

In the case of grinding corn to the average size of the product $M=1.44 \mathrm{~mm}$ (gap $1.5 \mathrm{~mm}$ ): the roller rotation speed $n=165 \mathrm{rpm}$, the angle of the guide $\beta=40^{\circ}$, the angle of the girth crushing plate $\gamma=10^{\circ}$. According to these values, the value of the specific energy consumption will be $2.78 \mathrm{kWh} \cdot \mathrm{t}^{-1}$, and the coefficient of variation $v=18.39 \%$. 


\section{Conclusions}

1. It has been experimentally confirmed that the achievement of a given grinding quality is ensured by changing the gap $\delta$ between the roller and the crushing plate and the roller rotation speed $n$. The energy performance of the grain grinding process also depends on the angle of inclination of the guide $\beta$, the angle of the girth crushing plate $\gamma$, the type of the processed raw materials and the degree of reduction.

2. Analysis of regression equations shows that increasing the roller speed and increasing the angle $\gamma$ of the girth of the screen of the roller increases the productivity of the crusher. Reducing the size of the product but increasing the unevenness of its fractional composition and specific energy consumption, the angle of inclination $\beta$ of the guide has almost no effect on the magnitude of the grinding modulus $M$. Insignificantly changes the coefficient of variation $v$, but increasing this angle increases the productivity of the the crusher. The value of the gap $\delta$ between the roller and the screen has the most significant influence on the process optimization indicators. Meanwhile, its value is determined by the size of the grinding products specified in accordance with the zootechnical requirements. With this in mind, rational parameters can be recommended: $n=160-165 \mathrm{rpm}$, $\gamma=10^{\circ}$.

\section{References}

[1] Шаповаленко О., Свтушенко О., Петренко А., Шатківська О. Подрібнення оптимізованих зернових сумішей (Grinding of optimized grain mixtures). Хранение и переработка зерна, 2017, № 11, ст. 31-33. (In Russian). [online] [20.01.2021]. Available at:

http://dspace.nuft.edu.ua/jspui/handle/123456789/26954

[2] Сердюк В. В. Дослідження процесу дроблення зерна ударно-сепараційним подрібнювачем (Study of grain crushing process by impact-separation grinder) Вісник Сумського національного аграрного університету. Механізація та автоматизація виробничих процесів. 2017. № 10, ст. 98-101. (In Russian). [online] [26.01.2021]. Available at: http://nbuv.gov.ua/UJRN/Vsna_mekh_2017_10_23

[3] Купчук I. M. Дослідження процесу подрібнення зерна дисковим ударним елементом (Study of grain grinding process by disk percussion element). Технічний сервіс агропромислового, лісового та транспортного комплексів. 2018, № 11. ст. 41-48. (In Russian). [online] [24.01.2021]. Available at: http://nbuv.gov.ua/UJRN/tcalk_2018_11_7

[4] Коротов Ю. Ю. Аналіз конструкцій подрібнювачів зернових кормів і напрямки їх вдосконалення (Analysis of grain feed grinders designs and their improvement directions) Вісник Харківського національного технічного університету сільського господарства імені Петра Василенка. 2017, вип. 181, ст. 62-70. (In Russian). [online] [24.01.2021]. Available at: http://nbuv.gov.ua/UJRN/Vkhdtusg_2017_181_13

[5] Wołosiewicz M., Foszcz D., Saramak D., Gawenda T. Analysis of a grinding efficiency in the electromagnetic mill for variable process and feed parameters. E3S Web of Conferences 18, MEC2017, pp. 1-6. [17.03.2021]. Available at: https://www.researchgate.net/publication/320204009_Analysis_of_a_grinding_efficiency_in_

[6] Flizikowski J., Kruszelnicka W., Tomporowski A., Mrozinski A. A study of operating parameters of a roller mill with a new design. AIP Conference Proceedings (2019). [17.03.2021]. Available at: https://aip.scitation.org/doi/10.1063/1.5091879

[7] Volkhonov M., Abalikhn A., Krupin A. Studying the operational efficiency of the centrifugalimpact feed grain crusher of the new design. Eastern-European Journal of Enterprise Technologies. vol. 5/1, (107), 2020, pp. 44-51.

[8] Mugabi R., Byaruhanga Y., Eskridge K., Weller C. Performance evaluation of a hammer mill during grinding of maize grains. AgricEngInt: CIGR Journal Open vol. 21, No. 2, 2019. pp. 170-179. Available at: http://www.cigrjournal.org

[9] Iskenderov R., Lebedev A., Zacharin A., Lebedev P. Evaluating effectiveness of grinding process grain materials. engineering for rural development. Jelgava, 2018, pp. 102-108.

[10] Lebedev A., Iskenderov R., Zhevora Y., Lebedev P., Marin N., Pavlyuk R., Zaharin A. Feasibility study of the grinding process of grain materials. Agronomy Research, vol. 18(3), 2020, pp. 2117-2126. 